Research Article

\title{
Women's Articles in National English Dailies: Coverage Priority and Issues Diversity
}

\author{
Shobha Aryal ${ }^{1 *}$, Arjun Karki ${ }^{2}$ \\ ${ }^{1}$ Department of Mass Communication and Journalism, Purbanchal University, Biratnagar, Nepal \\ ${ }^{2}$ Central Department of Journalism and Mass Communication, Tribhuvan University, Kathmandu, Nepal
}

Article Information
Received: 31 December 2021
Revised version received: 19 January 2022
Accepted: 21 January 2022
Published: 28 January 2022
Cite this article as:
S. Aryal and A. Karki (2022) Int. J. Soc. Sc. Manage.
9(1): $27-40$. DOI: $10.3126 / i j s s m . v 9 i 1.42717$
*Corresponding author
Shobha Aryal,
Department of Mass Communication and Journalism,
Purbanchal University, Biratnagar, Nepal.
Email: redvoice2021 @ gmail.com
Peer reviewed under authority of IJSSM
(O2022 IJSSM, Permits unrestricted use under the
CC-By-NC license.
OPEN 6 ACCESS
This is an open access article \& it is licensed under a
Creative Commons Attribution Non-Commercial 4.0
(https://creativecommons.org/licenses/by-nc/4.0/)
Keywords: Meda ana

\begin{abstract}
This study explores diversities, issues and priorities of women's articles in four broadsheet dailies in Nepal. The study has analyzed the ratio of national and foreign writers. It shoves into the number of women's writers and their areas/issues of writing. The study employs a content analysis research approach. It has extracted 351 articles of one month each national dailies of the year 2018. The articles have been encoded into appropriate fields and grouped under the eight different fields/areas. Then an analysis has been made on gender, issues, priorities and diversities of the articles. The findings are different in each newspaper. The Himalayan Times daily has been found more inclusive in terms of areas and gender priorities. The Kathmandu Post daily has been found to have been given least priority to national writers, regardless of women's writing. Similarly, the finding showed the largest variations in the Kathmandu Post in gender, issues and coverage. The Rising Nepal is found to have given more priority to national writers. Finally, the Republica daily has the second largest variations after the Kathmandu Post; however, the areas of writing have a great discrepancy. This study recommends for the positive discrimination to the women as stated in the gender related policies. The government, media and other stakeholders should play the facilitating role to monitor the media organizations for gender inclusivity in all the areas of work. Future studies focus on the wages, work flexibilities and responsibilities in media to promote peace, prosperity and holistic development of the nation.
\end{abstract}

Keywords: Media and Gender; Women Contents in Media; Women Journalists; Women Article Writers; Gender Inclusivity in Media

\section{Introduction}

Gender is always a debatable issue in the national and international platforms, seminars and conferences (Nepalnews.com, 22 May 2014). The gender is connected with pay, skill enhancement, gender priority, inclusivity in coverage and services, discrimination, staff proportion, nature of responsibilities and many more. According to World Economic Forum Report (2018) gender gap is a global issue. All the countries around the world have gender gap; however, in some of the countries strict policies have been implemented to minimize it. According to a news report in $\mathrm{BBC}$, Iceland has the least gap among all the countries (BBC News Report, 26 March 2014). Nepal falls in 0.671 (scale of measurement is $0-1$, with 0 : no gap and 1: the highest gender gap) and has been located in the rank of 
$105^{\text {th }}$ position in the Global Index (World Economic Forum, 2018).

The Constitution of Nepal 1990 was the landmark to honor women with distinct provisions of participation in all bodies of the state - education, employment social security and health on the basis of positive discrimination (part 3, article 38). The Constitution had guaranteed one-third of the total number of members elected to the Federal Parliament from the party (ibid, part 8, article 84). The Constitution of Nepal 2015 has continued with the provisions related to rights and guaranteed 33 percent of women participation in all mechanisms of the state.

While viewing the women's participation in Nepalese dailies, it is slighter and unstable. Women are provided responsibilities to write soft news, feature articles, women issues and such other so that they are thought to be more fitted on such areas. A survey conducted by Sancharika Samuha (2015) found that out of 1143 women journalists in Nepal, 46.5 percent have been provided responsibilities to follow soft social beats. Very few women have been provided to write on other beats- economic, politics, defense and international relationship.

Gender equality is also an indicator to measure the happiness and satisfaction level of employees in an organization. A male feminist scholar, Kimmel (2016) said in TED talk that "those countries that the most gender equal are also the countries that score highest in the happiness scale". The productivity and job satisfaction can also be achieved in an organization if gender equality has been maintained. A study by Catalyst (2018) showed that the organizations are more successful, maximize talents and productivity and reduce workplace harassment if gender equality has been maintained.

This study explores how the mainstream media maintains gender equality in its publication, the coverage, areas and priorities of women articles in four broadsheet dailies (English) in Nepal. The study has purposively chosen onemonth publication in each four English dailies - the Kathmandu Post (January), the Rising Nepal (April), the Himalayan Times (August) and Republica Daily (December). The data collected from the survey has been coded, quantified and analyzed for issues, priorities and diversities.

\section{Background of the Study}

This topic deals with the persisting the national scenarios of the women professionalism in the mainstream media, especially focusing on the print.

To be a journalist, the first and foremost requirement is media education. The general requirement for the journalism career is at least intermediate level of education. After attaining at least intermediate level of education, a journalism interested student can take the media related training and enhance their interest. In Nepal, the Population Census of Nepal 2011 found 50.4\% female population. The Nepal Living Standard Survey 2010-2011 (NLSS - III) found $56.6 \%$ adult literacy rates among whom female literacy is only $44.5 \%$ and rest is male. The Population Census 2011 reported that 622,012 female populations have at least intermediate level of education whereas 1,230,612 are male. The data shows that the ratio between the female of at least intermediate levels of qualification with male is about 1:2. This means when two parts is male then one part is female; female is one-third to total. Therefore, if all the employable institutions recruits at least one-third of the women for the employment, cent percent employable women participation will be ensured.

Gorkhapatra is the first media in Nepal. It started its publication from 1901 AD. There were no any female journalists in the starting phases. According to the Asian Development Bank (1999) female literacy rate (6 years and above) was $4 \%$ in 1971 AD. Nevertheless, in 1950s a group of women journalists had already started a magazine called 'Women'. The magazine earned a huge popularity among females and was a great inspiration. The first journalism college in Nepal - Ratna Rajya Laxmi Campus (RR Campus) started its PCL program in journalism in 1976 AD. In the history of Nepal, for the first time, journalism field incorporated female journalists. Nepal witnessed a phenomenal growth in media sectors during 1990s (Martin Chautari, 2009). The female literacy rate increased and reached to $27 \%$ in $1996 \mathrm{AD}$ (ibid).

According to a report prepared by Martin Chautari (2009) prior to $1976 \mathrm{AD}$, one learnt journalism by doing or through on-the-job-training/apprenticeship. Until then, the media industries had already prepared a small group of women journalists before starting the formal education.

In early $20^{\text {th }}$ century, different countries around the world were witnessing the first wave of feminism movement. Women were revolting for their rights - voting, sexual, reproductive and economic (Dorey-Stein, June 28, 2018). The movement laid a foundation for the establishment of women groups in different professional areas in different countries. In Nepal, according to Shrestha (2005) in 1950s, the monthly magazine called "Women" dedicated its publication with the gender related issues.

The Populations Census of Nepal in 1997 shows women participation in Mass Media to be 9.16 percent till the year 1997. Out of those, 12.3 percent were in the government sector and only 5.84 percent in the private sector. However, they were not in the policy making level in both the sectors. In detail about the female and male representation in stateowned media in Nepal from 1992 to 2002 is shown in Table 1. 
Table 1: The male and female representation in state-owned media in Nepal from 1992 to 2002

\begin{tabular}{lcccccc}
\hline Media & \multicolumn{2}{c}{1992} & \multicolumn{2}{c}{1997} & \multicolumn{2}{c}{2002} \\
& Male & Female & Male & Female & Male & Female \\
\hline Nepal TV & 79.6 & 18.4 & 79.4 & 20.6 & 78.3 & 21.7 \\
Radio Nepal & 91.6 & 8.6 & 91.8 & 8.2 & 69.9 & 29.1 \\
National News Agency & 93.6 & 6.4 & 94.3 & 5.7 & 91.8 & 8.2 \\
Gorkhapatra & 86.6 & 13.4 & 89.5 & 10.5 & 97.2 & 2.8 \\
Total & 86.7 & 12.3 & 87.1 & 12.9 & 84.3 & 15.5 \\
\hline
\end{tabular}

Source: Pandey (2017)

The Table 1 shows that from 1992 to 2002, ten years' duration, it has been increased by 3.5 percent in the number of female journalists professional in different types of media houses.

According to FNJ report 2013 (stated in Koirala, 2016) 1,613 out of 10,077 members of FNJ across the country were female. It is about 16 percent. In the same year Department of Information (DOI) stated that women journalist who received press accreditation from DOI was 7.5\%. According to a survey by Sancharika Samuha in 2005 stated that women journalist was 12 percent. The same organization conducted another survey in 2012 reported that the women journalists had soared to 24 percent. Therefore, the involvement of women in media has been in a positive trend. However, it is in a very slow in pace. There may be various reasons behind this. A survey conducted by Koirala (2010) found that the poor infrastructure and inflexible working hours are the major obstacles for women as journalists. In addition to these, every media has their own requirement policies depending on the nature of works. These are the hurdles for the women's professionalism in the media industries. Despite the sexy and fashionable jobs, an educated and potential female denies the responsibilities. According to a report published by Sancharika Samuha in 2015, the main reason behind the field lacking women journalists are discrimination (unfair treatment), irregular payments and minimum wages, unsafe working environment and inflexible work hours. Therefore, the diversity of women's issues in media has been a neverending discourse.

There are voices of female for their nature of work in the mainstream media. Ross (2004) discovered that female journalists do not believe that their journalistic practice differ much from those of male journalists. Similarly, Peiser (2000) found that agendas of male and female as a journalists were 'not too dissimilar'. However, it is believed and has a common understanding that women journalists in the news media provide shape and coverage of women's issues (Farley, 1978; Goodrick, 1991).

\section{Methods of Study}

The populations for the study are the articles in four broadsheet national dailies (English). Purposively the Kathmandu Post (January), the Rising Nepal (April), the Himalayan Times (August) and Republica Daily (December) of the year 2018 have been chosen for the study. The articles headlines and sub-headlines are extracted from the newspapers. They are coded under eight different areas. Then a textual analysis and interpretation of the contents have been made.

\section{Research Design}

The articles in the newspapers are the main data of the study. The objective of the analysis of data is finding the priorities of women articles, areas of issues and inclusivity with respect to gender. The Fig. 1 clearly illustrates in detail how the research has been carried out.

From the four newspapers, articles have been selected as data for the study. From articles, three types of data priorities of publication, articles writers and headlines \& sub-headlines, have been selected for study.

\section{Sample Selection/Sampling Technique}

Purposively four English dailies - the Himalayan Times (THT), the Kathmandu Post (TKP), myRepublica daily (MR) and the Rising Nepal (TRN) has been chosen for studies. The publication months are selected by following a simple random probability sampling without replacement method. A purposive sampling has been employed for the selection of main article page. In the sampling process, cheat of the pieces of paper with months in a year has been kept in a box. The card draws without replacement provided the result of the month's selection for the four national dailies. By this probability sampling, January for the Kathmandu Post, August for the Himalayan Times, April for the Rising Nepal and December for Republica has been chosen.

\section{Coding of the Sample Data}

The samples of the population for studies are national English dailies - the Kathmandu Post, the Himalayan Times, the Rising Nepal and the Republica. The sampling has been done using simple random probability without replacement technique. The opinions and articles in the newspapers have been chosen purposively (Table 2). 


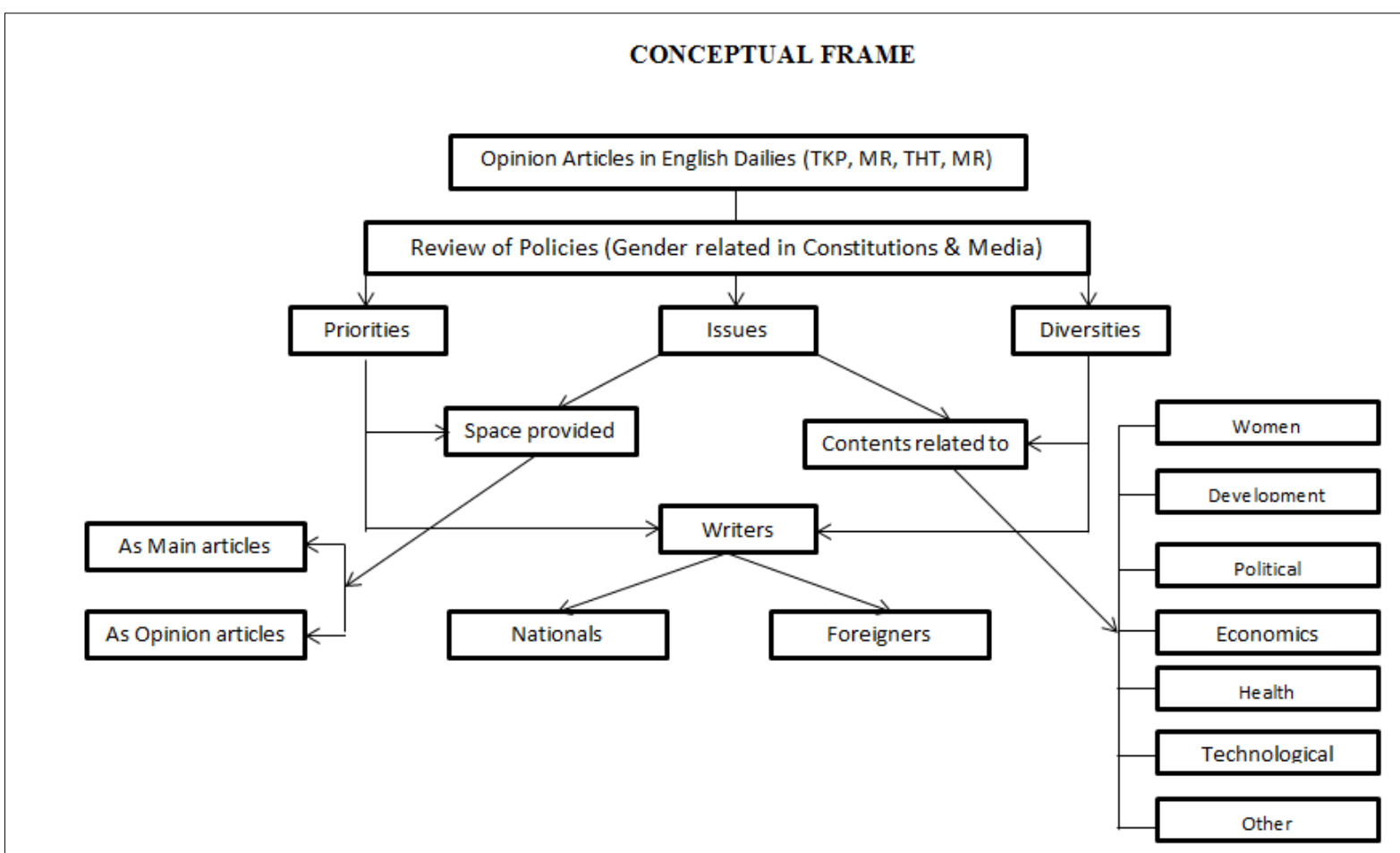

Fig. 1: Concept framework of the research [TKP - The Kathmandu Post, MR - My Republica, THT - The Himalayan Times, and TRN - The Rising Nepal]

Table 2: Sample Data

\begin{tabular}{|l|l|l|l|l|}
\hline S.N. & Name of Newspapers & Sampled months & Total issues & Number of articles \\
\hline 1. & The Kathmandu Post & January 2018 & 27 & 131 \\
\hline 2. & The Rising Nepal & April 2018 & 30 & 84 \\
\hline 3. & The Himalayan Times & August 2018 & 23 & 46 \\
\hline 4. & My Republica & December 2018 & 27 & 90 \\
\hline \multicolumn{2}{|c|}{ Total newspapers } & 107 newspapers & 351 articles \\
\hline
\end{tabular}

Table 3: Describe the details as heading of the table

\begin{tabular}{|l|l|l|l|}
\hline S.No. & Data Clusters of Studies & Processing Techniques & Coded into \\
\hline 1. & Headlines and sub-headlines & Coding of the terminologies & $\begin{array}{l}\text { Issues and Diversities - women , } \\
\text { political, economic, development, } \\
\text { education, technologies, health and } \\
\text { other issues }\end{array}$ \\
\hline 2. & Bylines & $\begin{array}{l}\text { Observation - counting and } \\
\text { recording }\end{array}$ & $\begin{array}{l}\text { Gender - male and female opinion } \\
\text { writers }\end{array}$ \\
\hline 3. & Nationalities of writers & $\begin{array}{l}\text { Observation - counting and } \\
\text { recording }\end{array}$ & $\begin{array}{l}\text { Nationalities - national and } \\
\text { foreigners - male and female }\end{array}$ \\
\hline 4. & $\begin{array}{l}\text { Articles publication } \\
\text { (location and space provided } \\
\text { for publication) }\end{array}$ & $\begin{array}{l}\text { Observation - counting and } \\
\text { recording }\end{array}$ & $\begin{array}{l}\text { Priorities in publication - main } \\
\text { articles, opinion articles or other }\end{array}$ \\
\hline
\end{tabular}




\section{Content Analysis}

According to web-portal of the University of Georgia, "Content analysis is a research technique used to make replicable and valid interferences by interpreting and coding textual materials. By systematically evaluating texts (e.g. documents, oral communication and graphics), qualitative data can be converted into quantitative data." It is clear from the definition of Content Analysis that it is a method of analyzing the qualitative texts in any formats by converting them into quantitative for the measurement. Bryman (2011) states the use of "Content Analysis" is to examine patterns in communication in a replicable and systematic manner. Therefore, this study analyzes the headlines/sub-headlines and overall 351 articles in four national dailies to find out their areas/fields. After that, they are coded into appropriate categories and presented quantitatively into graphs.

\section{Reviews of Policies}

\section{Gender Equality Goal in SDG 2030}

The United Nation has recognized Gender Equality as a Sustainable Development Goal (SDG) for its 2030 development strategy (UN - SDG 2030, Goal 5). Under this goal, there are nine targets (six of them are main targets and 3 sub-targets). The target number 5.5 explains "ensure women's full and effective participation and equal opportunities for leadership at all level of decision making in political, economic and public life." (Refer to SDG 2030, Goal 5, and target 5.5). The united nation has recognized gender equality as more than a fundamental right, it is necessary for a peaceful, prosperous and sustainable world. Gender equality will fuel sustainable economies and benefit societies and humanity at large.

Gender Provisions in the Constitutions of Nepal 2015

Between October 2015 and June 2016, Nepal received its first women in powerful positions-the President, the Speaker of Parliament, and the Chief Justice of the Supreme Court. This was momentous for women's rights movement in Nepal, and around the world. The new constitution of Nepal has reserved 33 per cent seats for women in federal and provincial parliaments. The results of local elections also brought a wave of women leadership in politics and governance, electing over 14,000 women leaders throughout the country.

The Constitution of Nepal 2015 has the provision of "Right of Women" under fundamental rights in article 38. There are six provisions related to women. The provisions (4) and (5) states about right to participations as:

(4) Women shall have the right to participate in all bodies of the State on the basis of the principle of proportional inclusion.
(5) Women shall have the right to obtain special opportunity in education, health, employment and social security, on the basis of positive discrimination.

In the above provisions, the first one state $t$ that women shall be included on proportional basis in all the bodies of the state and the second provisions states that women should be provided special opportunity in employment and social security on the basis of positive discrimination. In addition to this, National Women Commission has several provisions to ensure women's participations in different sectors. The commission has the provision to formulate policies and programs concerning the rights and interest of women. The article 253 states that the commission has to make provisions to include women in the mainstream of national development and carry out research on gender related issues and recommend reforming the related provisions in laws.

\section{Gender Policy in Federation of Nepali Journalist (FNJ)}

Federation of Nepali Journalists (FNJ) is a professional journalist's representation body in media - print, electronic and online, working across the country since 29 March 1956 AD. It is a member of International Federations of Journalists (IFJ) and International Freedom of Expression Exchange (IFEX) that has been working to promote and protect freedom of press, professionalism and security of journalists. Despite the long history, FNJ has no impressive gender ensured records (Sancharika Samuha, 2015). However, after the People's Movement of BS 2062/63 of Nepal, FNJ has become more inclusive in terms of gender and ethnicity. Many media organizations like, Press Union, Press Chautari, Federation of Nepalese Indigenous Nationalities Journalists (FONIJ), Krantikari Patrakarita Sangh, Madhesi Patrakar Sangh and other journalists' associations became inclusive with respect to women inclusion. But still the mainstream media has been working with patriarchal mentality that media organizations do not provide responsibilities to women. A survey conducted by Sancharika Samuha (2015) stated that 61.9 percent of the media organizations didn't have a separate gender policy in their organizations and about 24 percent remained silent on the inquiry, while 14.7 percent said that they have separate gender policy.

\section{Mass Communication Bill 2018 (2074 BS)}

The Mass Communication Bill 2018 enshrined the values of the Constitution of Nepal 2015. The main focus of the policy lies in directing the mass communication for fair, dignified, responsible and accountability. It states about proportional inclusion and participation to create equitable society. The policy has included objective as enhancing access to all class of people, gender and ethnic groups, as per the national policy of inclusion. The active representation of women, dalits, indigenous nationalities and people with disability has been ensured (1.4). The 
policy draft was criticized by many stakeholders and media persons for the weakness in ensuring all the dimension of fundamental rights to speech, information, freedom expression, press and publications and other. Even in the gender representation provisions, Taranath Dahal, policy experts (associated with Freedom Forum Nepal) criticized the provisions are limited to mere acts of encouraging (Dahal \& Sigdel, 2016).

\section{Data Presentation and Interpretations}

Dealing with the areas of women in print newspapers, the data analysis moves from broad to narrow and to the narrower areas as far as possible. From the evaluation of men and women article writers in the national dailies, it shoves further into priorities provided to women articles in the national newspapers and also types of issues of both gender and then female only. Even further, it extracts issues that national and foreign women write and get published. Introduction to each topic has been summarized in the following paragraphs.

\section{National and foreign articles writers}

The Fig. 2 presents the national picture by analyzing the coverage of articles writers in two categories i.e. nationals and foreigners. The distinction of the nationals and foreigners has been based on the text analysis. The analysis of the second name (caste) of the writer has been done to distinguish. The category includes all the national writers or international writers of the Nepali origins. This analysis has opened space to argue the coverage priorities of the national dailies. The ground of consideration is the more national dailies prioritize to include writers from within the nation the more women get space to express their voices.
The Fig, 2 illustrates a comparative data of national and foreign article writers in four national English dailies TRN, MR, THT and TKP in four different month of the year 2018. It depicts the total number of articles along with the number of national and foreign writers. The graph clearly shows the four national dailies have different inclusive policies in regards to writers of national and international.

The total number of articles in TRN is 84 , similarly in MR is 90, in THT is 46 and finally in TKP it is 131. Out of the total articles in the four national dailies the foreign writers are more in TKP which is about fifty percent to the total. There are 64 foreign writers out of 131 articles of and the rest 67 are national writers. This shows that the TKP gives priority almost equal space to national and foreign writers in its broadsheet daily.

The state-owned newspaper daily, TRN - April data shows that it gives more priority to national writers, almost seven times of eight (i.e. 7/8). Out of 84 articles 74 articles are found to have been written by the national writers in the month of April 2018. Only 10 articles are provided space by the foreign writers.

With respect to ratio, similar situation we can observe in the THT - Aug. as well. It is found that national writers are almost equal to the total numbers of articles, except a few foreign writers. There are 40 national writers out of 46 articles in the month of August 2018. A few foreign writers' articles are published. In comparing this with ratio, we can find that it is almost one by eight (i.e.1/8) part.

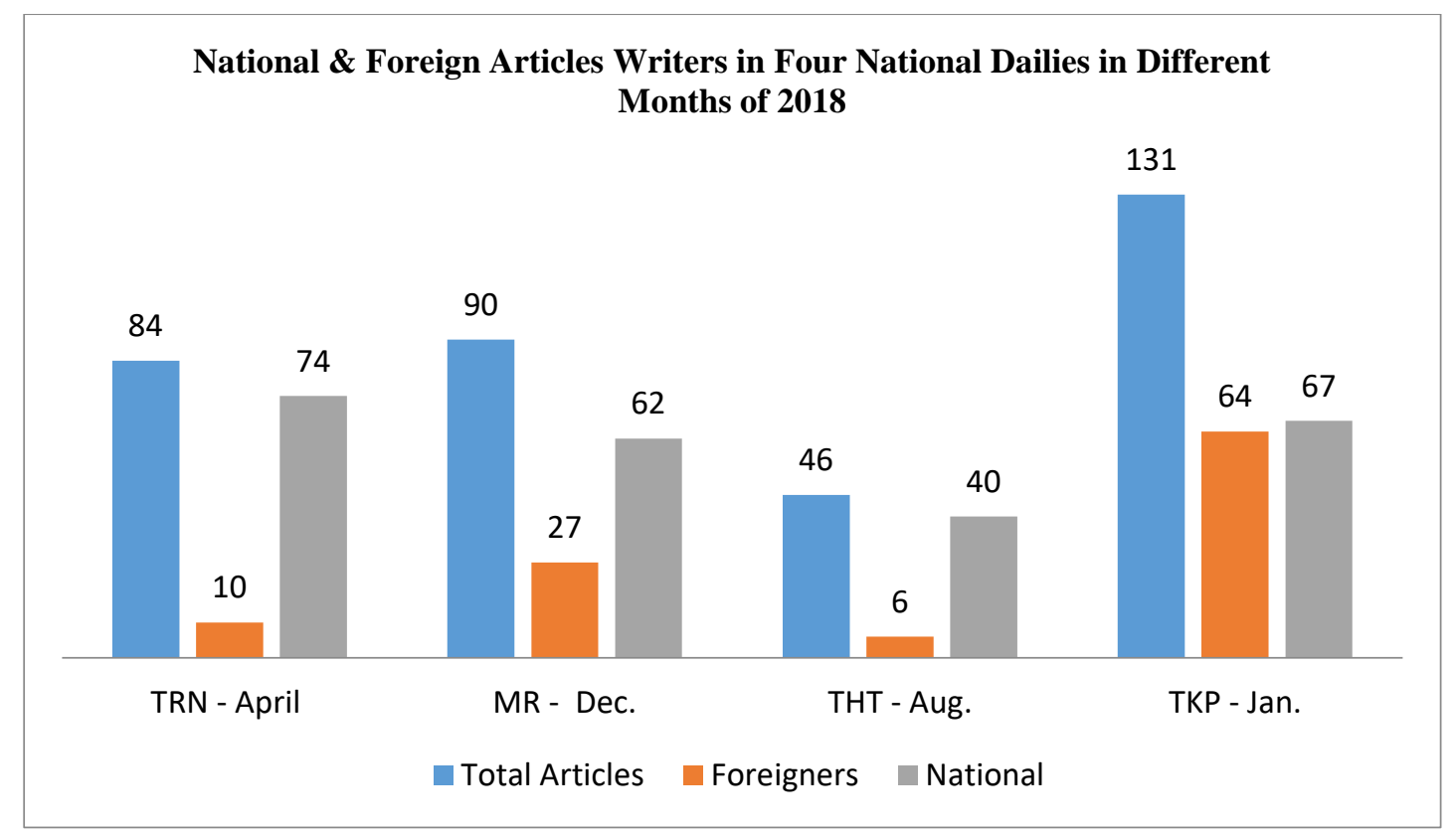

Fig. 2: National \& Foreign Articles Writers

[Abbreviations: TRN - The Rising Nepal, MR - My Republica, THT - The Himalayan Times, TKP - The Kathmandu Pos 
The MR- Dec. data shows that it has given priority to foreign writers almost one third to its total number of articles in December month 2018. There are 27 foreign writers out of 90 articles in a month. On the other hand, the national writers are more than twice of the foreign writers. The national writers are 62. It is more than two thirds of total articles.

\section{Percentage of Women Writers}

Out of the sampled data, a comparative study of female writers in national dailies has been made. It provides us ideas about the percentage of inclusivity of women articles with respect to total published articles. This part of data gives the overall strategy of communication of the media organization. There widespread debate about the gender inclusivity in media organization. Mainly the perception of such debate is also because of their coverage. Therefore, this section directly implies on the policy or principle aspects of the organization.

The Fig. 3 illustrates percentage of women writers and total number of articles published in four national dailies in 2018. The total numbers are real value whereas women writers shown in the graphs are percentage values. The illustration provides knowledge about the inclusivity of the women articles in national English broadsheets.
The TRN - April is found in the least percent of women articles. Only $6 \%$ of women articles are published. The total number of articles is 84 in TRN. With respect to providing space to women writers, MR-Dec. is found in $21 \%$. The MR has more space as it published 90 articles in the month of December 2018. It means almost three articles each day.

The THT has been found in a better position. The newspaper has provided $39 \%$ space to women writers in the month of August 2018. Out of all the newspaper in consideration, the THT is most inclusive with respect to gender. Though it has least articles daily, only two articles each day, it is more inclusive.

\section{Areas/Fields of Article Coverage}

The data shown in Fig. 4 provides analysis of different areas of articles. The divisions of areas have strictly been done by coding the terminologies used in headings and subheadings. As per the need altogether the articles are divided into eight areas. The focus of this part is finding on what types of issues the national dailies generally cover in its article sections. How far the women issues get published in the national dailies?

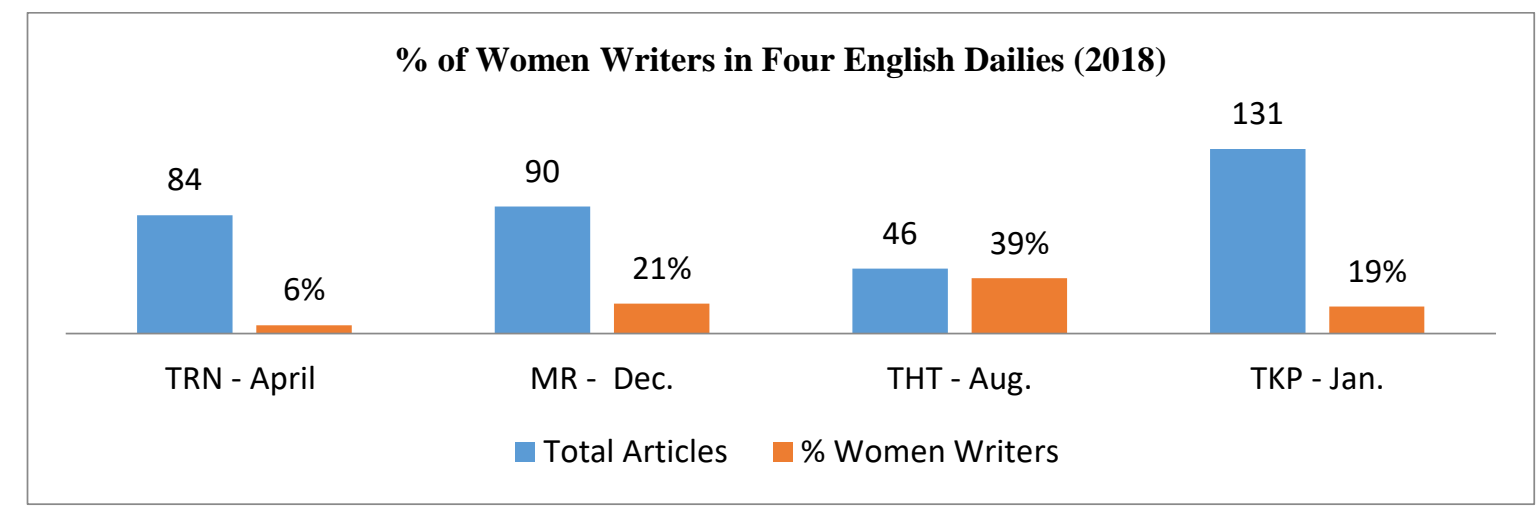

Fig. 3: Percentage of Women Writers in Four English Dailies

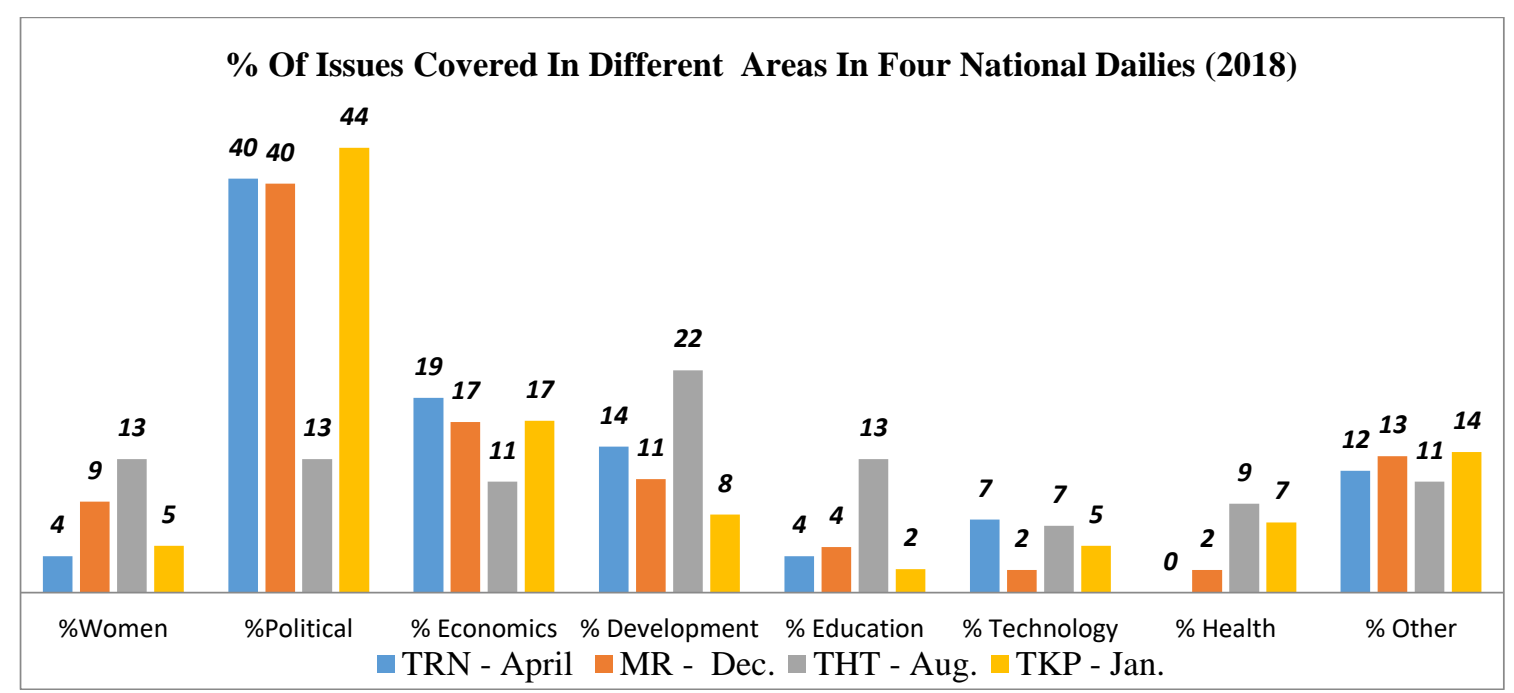

Fig. 4: Different areas in four national dailies 
The Fig. 4 shows areas percent of issues covered in four national dailies in 2018. It illustrates altogether eight areas - women, political, economics, development, education, technology, health and other issues. The articles have been divided under the categories of these areas published in newspaper of four different months in 2018.

The Fig. 4 shows a balanced view of THT - August than any other newspaper. In terms of women issues too, it has provided 13 percent space and is more focused in developmental issues. THT covered 22 percent in developmental issues and three areas it covered 13 percent equally - women, political and education. In remaining areas, it has covered 9 percent health issues. Similarly, it has provided space for $11 \%$ economic issues and same percent of other issues. It is found only $4 \%$ women issues have been covered in the TRN - April. TRN is the state-owned media and it is devastating result that not only it has given less priority to women issues but there are no any issue related to health. It shows that $0 \%$ articles in the health sector. The maximum priority the newspaper has given is political issues, which is $40 \%$ coverage out of total issues of the month. The second highest is $19 \%$ in economics issues. Similarly, it has given $14 \%$ priority to development issues. On the other hands if we analyze the second least prioritize area, we can find education sectors. There are only $4 \%$ articles related to education in the newspaper. In the information and technology, it is found $7 \%$ and in the rest of the issues, there are $12 \%$ articles.

If we analyze the political issues, we can find $44 \%$ priority attentions grabbed by TKP -Jan. It is significantly highest coverage areas in any other newspaper. The newspaper provided almost equal space to national and international writers, and may that be the reasons behind the highest coverage of political issues in the broadsheet. The articles in the education sectors is very less, which is just $2 \%$ and the second least is $5 \%$ in women sectors. On the other hand, $17 \%$ of articles have been found in the economics sector, which is the second highest. Similarly, $8 \%$ in development,
$7 \%$ in health, $5 \%$ in technology and $12 \%$ on the other issues have been found. Overall the bar shows most variant than any other broadsheet dailies.

Finally, the MR -Dec. bar shows in the second place out of four dailies with respect to women issues coverage. It has provided 9\% articles out of total December issues. In its overall picture, the women issues are provided second least coverage. The highest space was provided to political issues which is again $40 \%$ as like that of TRN - April. It covered $17 \%$ and $11 \%$ issues in economic and in development respectively. The least significance it has provided to technology and health areas; only $2 \%$ of the articles have been covered in each area. In second least is an education article, which is just $4 \%$ of the articles. On the other hand, in the rest of the areas we can find $13 \%$ of the articles. In the overall picture emphasizing to women issues, it is found to be second better as it has given second highest space to women issues.

\section{Number of women's articles on different issues}

It presents the issues of women writers (national and foreigners) who are writing in the national dailies. It provides the ideas on what types of subject matters (topic) the women writers are writing and getting published in the national dailies. The data analysis clarifies the issues that basically women are offered to write and also provides areas of debate on why in the other issues they don't write. It lets know the lacking areas with respect to inclusivity on issue based areas.

The Fig. 5 shows the number of articles written by women on different issues in four national dailies in 2018. Here, the women not only include native female people but foreigners as well. Fig. 5 gives idea on what type of issues women particularly write and get published. The figure shows a great variations especially in political and other issues in which it is found two bars vertically raised more than twice of the normal bars. Similarly, some of the broadsheets even don't any issues and found zero.

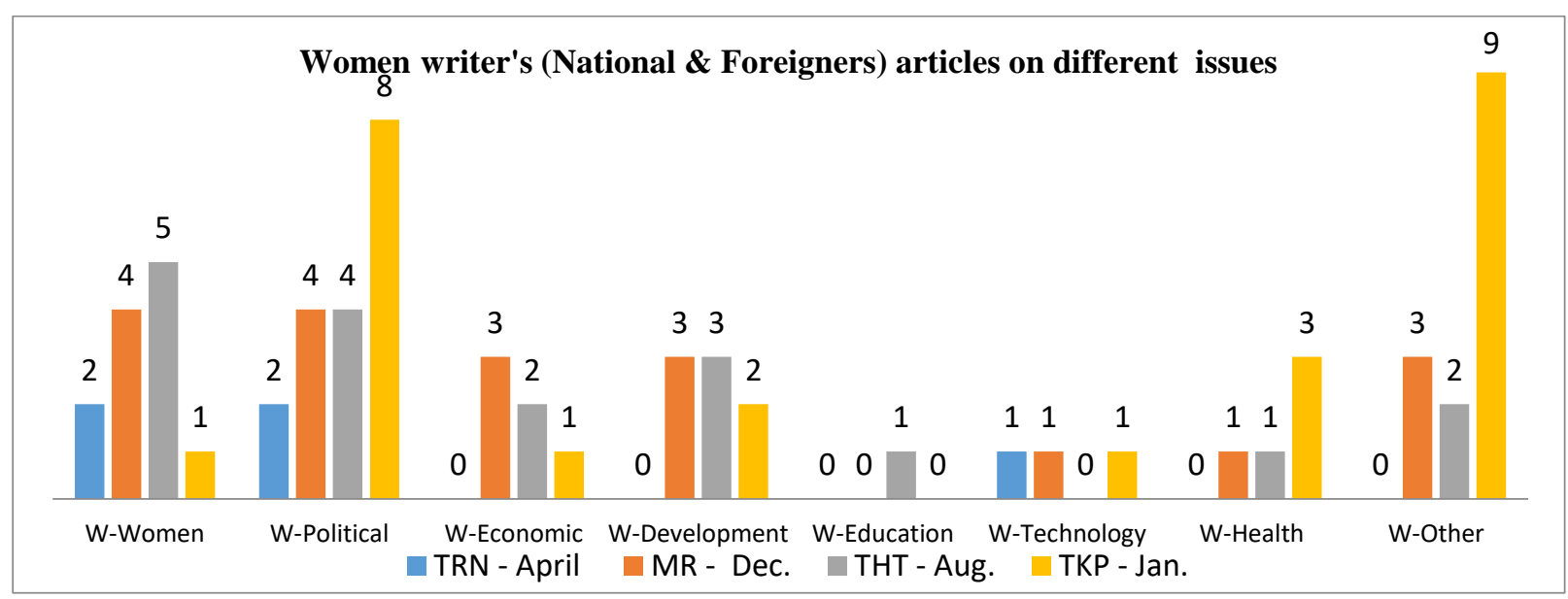

Fig. 5: Number of articles written by women on different issues in four national dailies in 2018 
It can be seen that the bars of the THT - Aug. is balanced as it maintains less variations in all the eight areas. In women category, 5 issues have been noted by the women writers, which is the highest number than any other writings by them. In the second place, there is political issue. Altogether 4 articles have been found in this category. Similarly, the least writing have been noticed in education and health. There is one article in each. The second least category is economic and other, in which there are two articles in each. Political issues have been found in the second largest coverage. There are 4 articles related to political issues. The next, largest category is the development related issues. It has been noted 3 articles in the development related areas.

Focusing on women's issues, another highest number of writings have been found by MR- Dec. newspaper. There are 4 articles related to women issues written by women. Slightly less writings have been noted in political issues. There are four articles on political issues. Three articles each are found in three areas - economic, development and other. Similarly, one articles each in two categories technology and health. No any article has been noticed in education issue. This is very clear that women writers are competent in all the key areas.

The most variant findings have been estimated with the TKP - Jan. issues. In this newspaper, the Political and Other category have vertically skied bar more than twice of the average bar lines. In the political issues there are 8 articles and in the other category there are 9 articles written by women in the month of January 2018. In the rest of the areas, there are less than 4 articles in each. For instance, in health areas, 3 articles have been found. In women category only one article is found. Similarly, one article in each has been found on economic and technology issue. No any article has been found on education issues and two articles have been found in development issues. In overall, the broadsheet shows women have capabilities to write not only in women related issues but equally on political and other issues.
The TRN - April has a total 5 articles on different sectors. It is found the prioritize area of TRN in April 2018 is women and political issues. It means the media has given women issues and political issues as priority written by women. In the technological sectors, only one article has been found. In the other sectors, no any articles have been noted. The data shows that there are no any articles related to health and other issues.

\section{Publication Priorities of Women's Articles}

The fifth topic is about the analysis of priority provided to women articles by the print media while in print. For this, article in the editorial page at top has been counted the most prioritize (main) article and the article appearing below the editorial writing is second prioritized article. Similarly, articles appearing below than that or in the next page have been calculated as less significant or least significant.

The Fig. 6 illustrates priorities given to women articles in print in the four national dailies - TRN, MR, THT and TKP. The data shown inside the bars are total number of the articles written by women in the dailies. It shows a great discrepancy as it depicts least priority has been provided to more articles.

In the least priority sections there are 20 articles in TKP Jan., 5 articles in TRN April and 12 articles in MR - Dec., whereas there are any articles in THT - Aug. The reason behind no articles in THT is that it has only two articles space. However, while checking the number of the highest prioritized articles, it can be seen that in THT - Aug. there are 6 articles. In the two newspapers MR and TKP only two articles are found to have been printed in the highest prioritize section. No any article of women has been found as the highest prioritize in TRN April. In the second priority, 12 articles of women are found in THT - Aug., 5 articles in MR - Dec., 3 articles in TKP - Jan. and 1 article in TRN April. In all the newspapers, the data shows that second priority articles have been at least available.

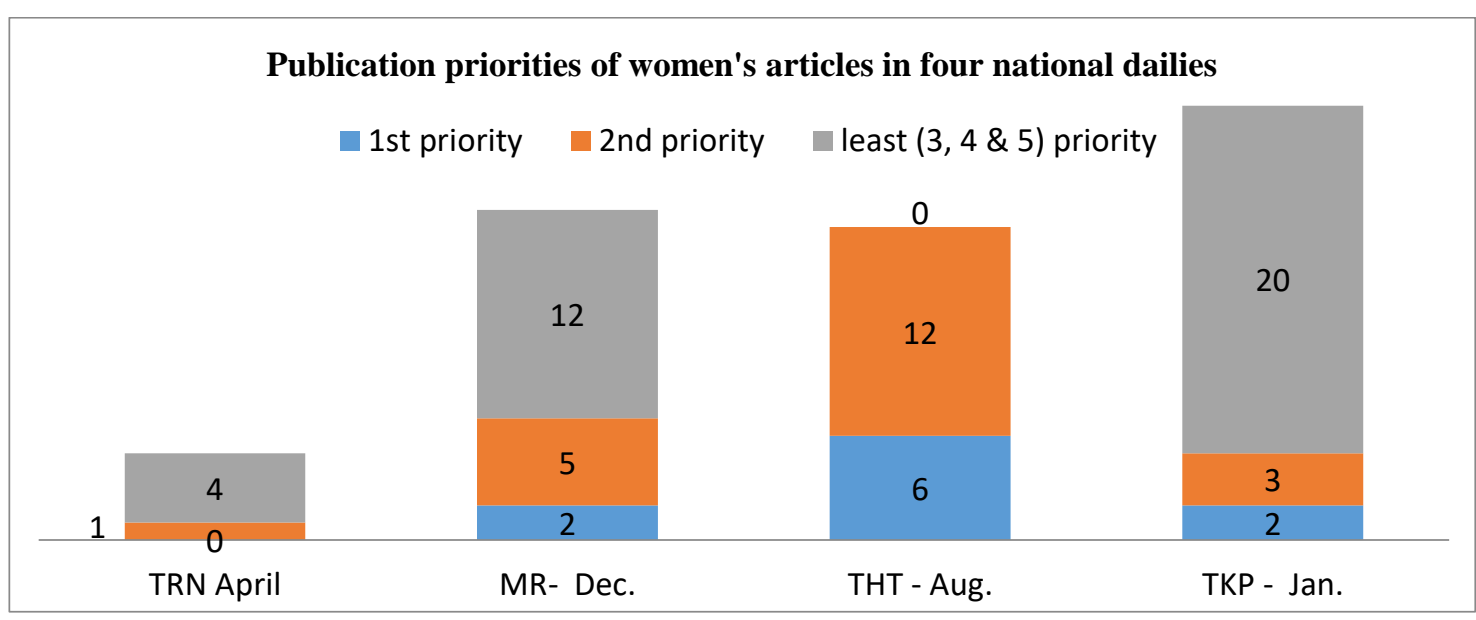

Fig. 6: Priorities given to women articles in print in the four national dailies 


\section{Foreign women writers and their areas of articles}

It concerns about the foreign women writers and their areas of articles. Minutely it analyses on what issues the foreign women writers are publishing their articles in the national dailies. It clearly demonstrates with evidences on what areas national women writers or willing to be a writer have to develop their capabilities, on one hand and on the other, more importantly, it also provides evidences how international agendas influence Nepal.

The Fig. 7 illustrates foreign women article writers and their areas of writings in the four national dailies - TRN - April, MR - Dec., THT - Aug. and TKP - Jan. 2018. The chart shows interesting information variation with respect to political issues and other.

The print provided greater political issue coverage than any other. In TKP, it is found that 7 articles are related to political subject matters. Similarly in all the newspapers, there are above minimum number of articles in political areas. 3 articles have been found in TRN - April, and 2 articles in each have been found in THT - Aug., and MR Dec. Similarly, in all the newspapers the articles related to economics have been found. 2 articles in each have been found in MR - Dec. and TRN - April and 1 article in each have been found in the remaining two newspapers, THT Aug. and TKP - Jan. In the other categories, mostly there are less foreign articles writers except health issues. Two articles have been found in TKP - Jan. related to health and one article in MR - Dec. On the other category, 6 articles from foreign writers are found in TKP - Jan. and only one article in MR - Dec. No any articles from foreign women have been found in education sectors in the four newspapers. In the women related issues, only two foreign writer's articles have been found. One article has been found in TKP - Jan. and one article in MR- Dec. newspaper.

In overall, the foreign women writers have been found more interested to write in the political issues and they have balance coverage in economics issues. On the other issues, there are lots of variations.
National women article writers and their areas of writings It deals with the national women articles and their issues of writing in dailies. It provides idea about the type of issues written by women writers and get published in the broadsheet.

The Fig. 8 illustrates national women writers and their areas of writings in four national dailies. The data shows least variations except TKP and MR newspapers. The most interesting is that in all the newspapers equal number of articles by national women writers have been found in development issues. Similarly, no any articles have been found in technological issues.

The THT - Aug. includes 5 articles in women issues which is the highest number of articles o $n$ the particular issues in the four newspapers. In TKP - Jan. no any article has been found. On the rest of the two newspapers, 3 articles in each have been noted. In political issues, no any women article have been found on TRN broadsheet, whereas 2 articles on each MR and THT have been found. Similarly, one article has been seen in TKP. In economic issues, 3 articles have been found in TRN written by national women writers and one article in each MR and THT newspapers have been noticed. There is no any article in this issue in TKP - Jan.

On the other issues, the data shows inconsistencies. For instance, in the health issues, 4 articles have been found in TKP - Jan., whereas no any articles have been seen in two newspapers MR and TRN. As in the same way, there are slight discrepancies in 'other' issues. 2 articles have been seen in THT and no any article in MR and TKP, whereas only one article in TRN.

Finally, in education issues, we can find equal number of articles in two broadsheet dailies - TRN and THT but no any article in the remaining two newspapers.

In overall, national women article writers are competent enough to write in diversified issues. Still, they are found to have been covering or being responsible more in women related issues.

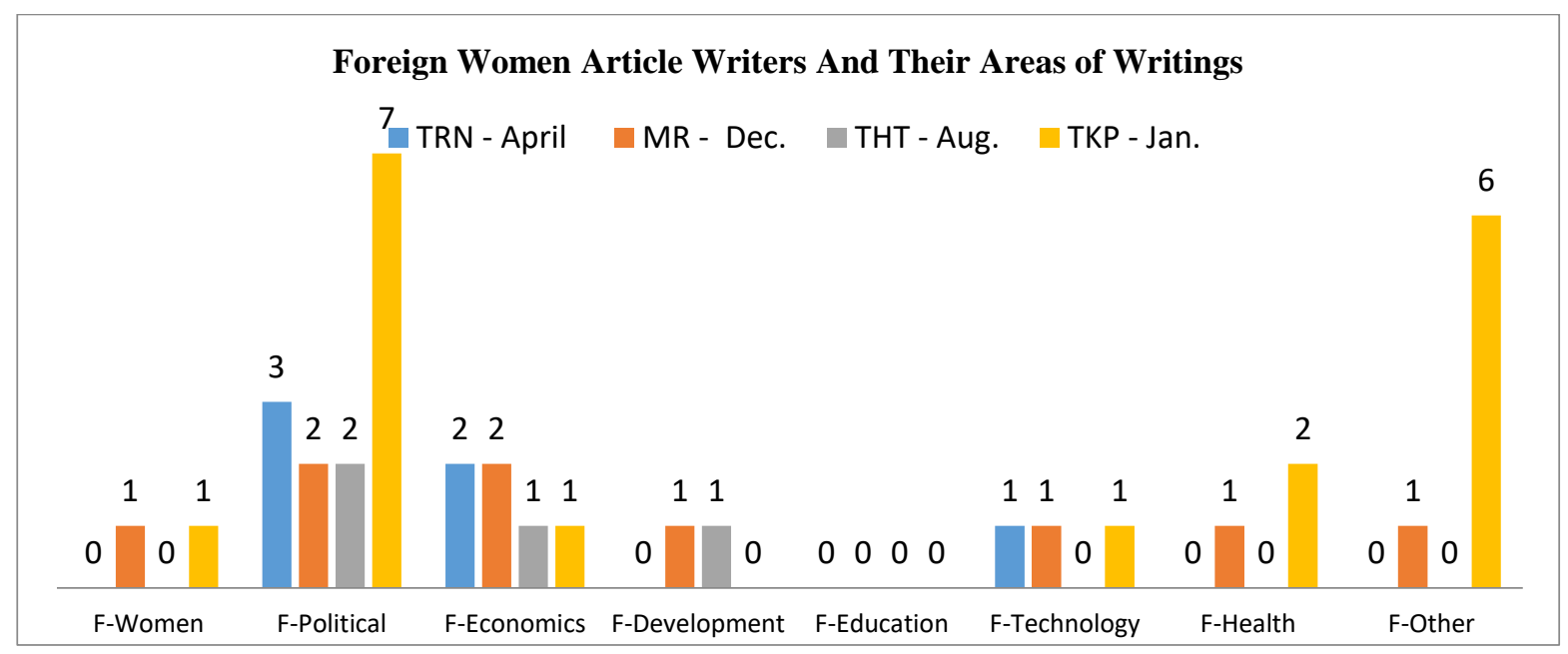

Fig. 7: Foreign women article writers and their areas of writings 


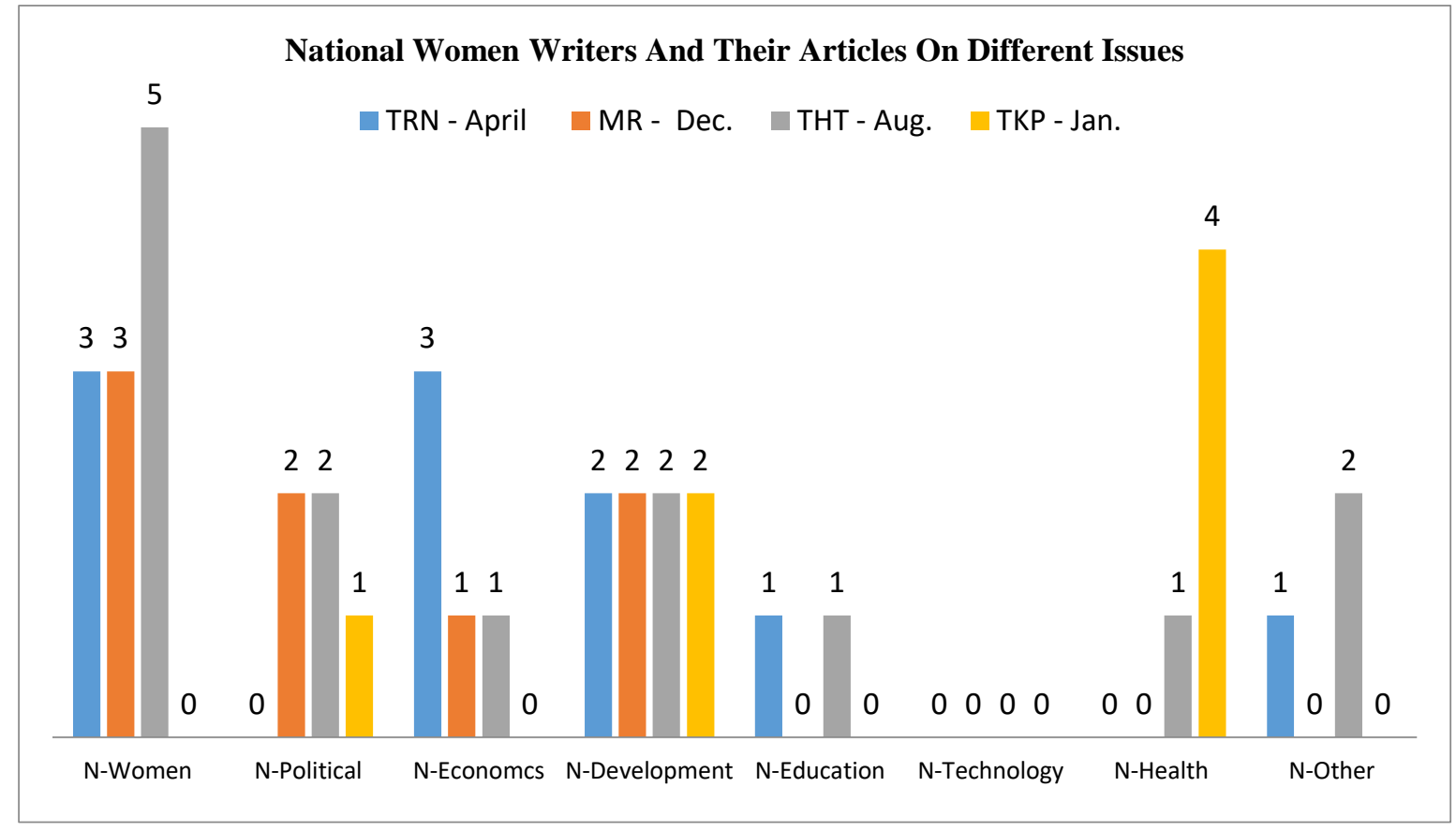

Fig. 8: National women writers and their areas of writings in four national dailies

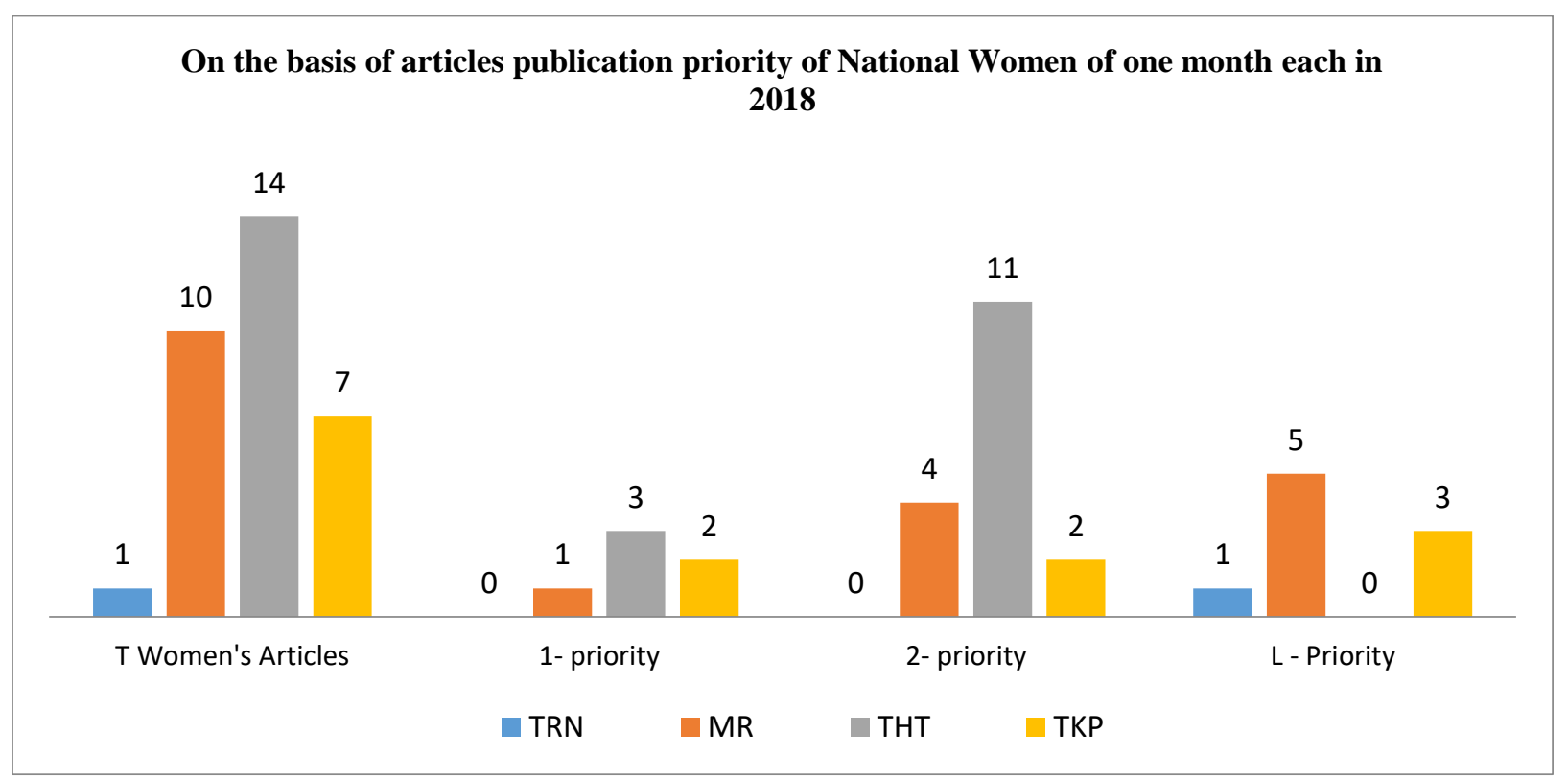

Fig. 9: National women writers' articles publication on the basis of priority

\section{National Women's Articles Publication Priority}

The Fig. 9 illustrates national women writers' articles publication on the basis of priority. The first bar with named "T Women's Articles" means total women articles in the four national dailies. The data shows that more national women's articles have been published in the second priority. The THT includes only two articles in its broadsheets. Out of the two articles, it shows 3 articles in the first priority. It is the biggest number out of the four national dailies. Similarly in the second priority too, it has published 11 articles. No any articles have been found in the first and second priority of the TRN newspaper. With respect to MR daily, there are 10 women's articles in total. The order of the article publication is different -in the first priority it has 1 article, 4 articles in the second priority and 5 articles in the least priority. 


\section{On the basis of articles publication priority of Foreign Women of one month each in 2018}

$\square$ TRN $\square$ MR $\square$ THT $\square$ TKP

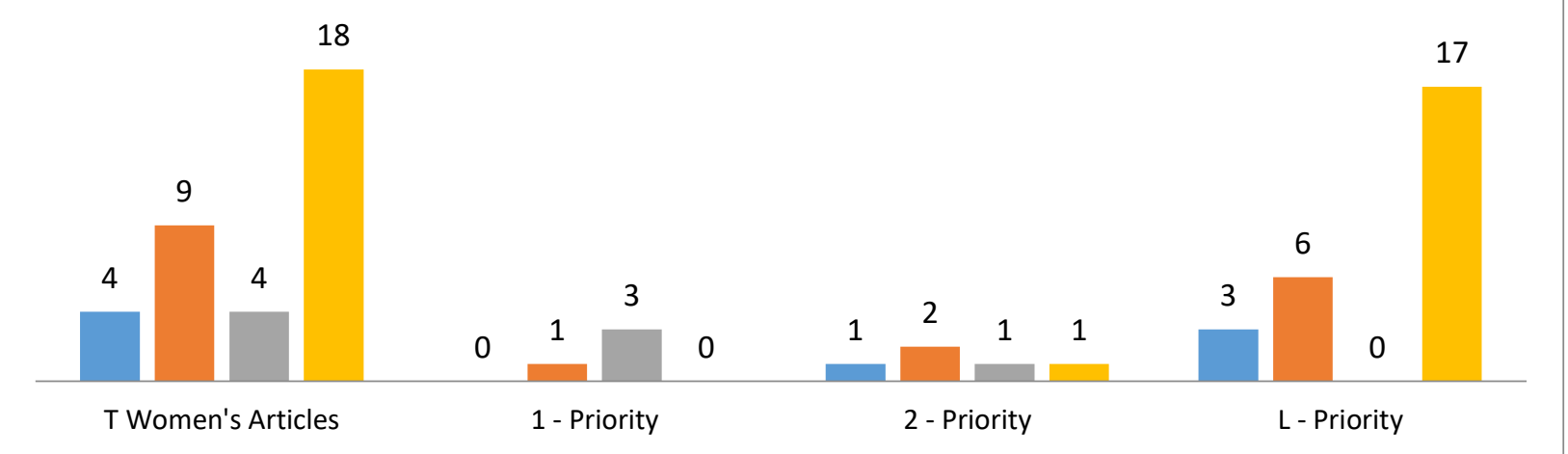

Fig. 10: Foreign women's articles publication priority in four national dailies

\section{Foreign Women's Articles Publication Priority}

The Fig. 10 shows foreign women's articles publication priority in four national dailies - TRN, MR, THT and TKP. The first bar with bar named 'T Women's Articles' shows total number of foreign women's articles in four national dailies, one month each in 2018. The highest total number of foreign articles has been found in TKP. There are 18 articles and all of them except one have been published in least priority, one of them to have been published in second priority. The THT is found in balanced proportion. There are four foreign women's articles in THT and out of it, 3 are in first priority and one of them in second priority. With respect to MR, there are 9 articles in total from foreign writers. One of them have been published in first priority, 2 of them have been published in second priority and remaining 6 articles in the least priority. The greater variation lies with TRN. Altogether 4 foreign women's articles have been noticed in TRN. With TRN, no any articles have been noticed in the first priority, only 1 article in second priority and the rest of the 3 articles in the least priority. In overall, from the result it is seen that least priority has been paid to women's articles publication.

\section{Discussion}

According to Federation of Nepal Journalists (FNJ) there are 13 thousand 50 journalists in Nepal and out of them 2 thousand 3 hundred and 54 are women journalists (cited in Nayapatrika, 8 March 2020). It further states that maximum female journalists leave the job when they reach 30 years of age. Nitu Pandit from Sancharika Samuha and Yashoda Timilsina, the Information Commissioner at National Information Commission has a single voice and expressed their dissatisfaction with 'women unfriendly environment'. They both agree that one of the major reasons for women quitting journalism jobs is an unfriendly environment (ibid, para. 3-4).

Women face many hurdles or difficulties while working in the media organizations, Bhimsen Thapalia, works in editorial department at the Rising Nepal, rather argue that the reason are the lack of quality education because of which women are not empowered and they lack language competencies or command over English language (Personal Communication, Bhimsen Thapaliya, 10 November 2020). The other reasons Kosh Raj Koirala, a senior correspondent from Republica daily states that are the family obligations, wages system and job timing especially with regards to print (Personal Communication, Kosh Raj Koirala, 15 September 2020).

The editors of all the media organizations strongly expressed their dissatisfaction for women being provided the responsibility of writing soft-news only. 'Educated and capable women can write in any issues and we can send them to collect any types of news as per their interest and skills,' states Kosh Raj Koirala in the interview, about changing gender discrimination stereotypes. Bijaya Lal Shrestha, a Consultant at The Himalayan Times further adds that women writers - doctors, members of parliaments, teachers and others write in any topics - politics, health, education, social issues and other. The consultant has also made a remark about the competency in language, "most of the women writers are regular contributors who have a command over language' (Personal Communication, Bijaya Lal Shrestha, 12 September 2020).

In all the areas the involvement of the women is less though the Government of Nepal has policy of positive discrimination with respect to gender equality. With this regard, journalists from Rising Nepal accept that women writers are not as active as male writers but they are encouraging and trying their best to provide space in the print. With regards to foreign women writers and Nepali women writers, journalists and editors have the same voice that they don't discriminate on the basis of nationalities, rather priorities are given for the best and contextual write ups. However, they accept that good education, exposure, 
experiences and a suitable environment to groom in the journalistic career may be the hidden factors.

In contrast to general perceptions, journalists and editors of the main-stream media express to have a given higher priority to women writers. In line to this, Bijaya Lal Shrestha, Op Ed consultant at The Himalayan Times states that media houses are often blamed to have provided soft news issues to women journalists but that is not the case in reality. 'Women themselves have to decide what they want to write in their field of expertise,' states Bijaya Lal in person communication with the researcher. The consultant further expressed that the THT is women friendly and very responsive to gender issues in terms of matter of content. Writing requires great skill, which cannot be developed overnight. It takes years and years of writing, maybe throughout life to be able to write a good piece. Language proficiency is a must if you want to write and express oneself - more so in an English paper in the Nepali context. Nothing comes easy, hard work and dedication is required. In contrast to the opinion of Bijaya Lal, Bhimsen Thapaliya, a journalist at OpEd department of The Rising Nepal accepts that they have not met the policy of $33 \%$ of women involvement. The journalist states the reason ranges from education, interest, economic to other aspects of sociocultural dimensions. However, the Rising Nepal is always in favor of the policy and looking forward to providing every possible opportunity to empower women.

\section{Conclusion}

The women article writers are getting respectively less coverage in the four broadsheet dailies. The finding shows that only the Himalayan Times has a balance policy to cover all the dimensions and issues. The rest of the newspapers finding shows great discrepancies. Despite the practical difficulties, the media owner should have a mindset of implementing a balance policy. Many studies show that inclusivity issues, coverage and priorities not only increase readers but enhance its credibility. The national women's articles are found to have been published covering mostly soft articles like features writing, women issues, food, music and developmental issues. But, the foreign women, in the same newspapers, are found to have been getting coverage massively in political, security, technology and bilateral relation issues. Therefore, this paper argues for equality in platform to women writers regardless of their nationalities. Even with regards to publication prominence, a trend of providing least priority to women's articles has been found. If media house implements a strict gender inclusive policy, many human resources issues like staff turnover, job satisfaction, harassment and other will be resolved besides increasing subscriptions and sustaining media credibility. To sum up, the editors of the prominent media have accepted the findings of the study. Concerning with the persisting problems of gender inclusivity in the news contents, their response have been noted in multiple dimensions - lack of human resources, security and work environment, pay scales, patriarchal society and people's mindset, work time-table and other. Most of the editors who have been interviewed have accepted these factors related to the findings of these studies. Some of the media organization like, Kantipur and the ACPA house have made head-hunting for the interested women journalists in order to make their team inclusive. Some of the editors like Kapil Kafle (editor of Kamana Prakashan) have long been advocating for the gender equality and gender inclusivity in news reporting, however, states aforementioned factors for the existing problems.

\section{Acknowledgement}

The study has received funding from the University Grant Commission, Nepal. I would like to express a big thank you for the fund that they made available for the study.

\section{References}

Asian Development Bank (1999). Country Briefing Paper Women in Nepal. Retrieved from: https://www.adb.org/sites/default/files/institutionaldocument/32561/women-nepal.pdf

BBC News Report (26 March 2014). What Stands in the way of Women Being Equal to Men? [Accessed on 20th Oct. 2019]. Retrieved from: https://www.youtube.com/watch?v=ayj9EVc2ZLI\&t=17 $\underline{25 s}$

Bryman A (2011). Business Research Method. UK: Oxford University.

Caine B (2018). All About Suffragettes to Social Media: Waves of Feminism. Retrieved from: https://www.youtube.com/watch?v=HWp-DoFnL6Y

Catalyst (1 August, 2018). Why Diversity and Inclusion Matters: Quick Take. [Accessed on 20 Oct. 2019]. Retrieved from: https://www.catalyst.org/research/why-diversity-andinclusion-matter/

Dorey-Stein C (June 28, 2018). A Brief History: The Four Waves of Feminism. Retrieved from: https://www.progressivewomensleadership.com/a-briefhistory-the-four-waves-of-feminism/

Farley J (1978). Women's magazines and the equal rights amendment: Friend or foe? Journal of communication, 28(1), pp. 187-92.

Gerdes K (2017). HUM16 Arts and Ideas American Cultures: Second Wave Feminism. Retrieved from: https://www.slideshare.net/KirstenGerdes/hum16second-wave-feminism

Goodrick ET (1991). Editorial Writers: Approaches to selected women's issues. Newspaper Research Journal 12(3), pp. 20-31.

Government of Nepal, Central Bureau of Statistics (2010-2011). Nepal Living Standard Survey. Retrieved from: http://siteresources.worldbank.org/INTLSMS/Resources/ 
$\underline{3358986-1181743055198 / 3877319-}$ 1329489437402/Statistical_Report_Vol1.pdf

Government of Nepal, Central Bureau of Statistics (2011). National Population and Household Survey. Retrieved from: $\quad$ https://unstats.un.org/unsd/demographicsocial/census/documents/Nepal/Nepal-Census-2011$\underline{\text { Vol1.pdf }}$

Kimmel M (6 Oct. 2016). Why Gender Equality is Good for Everyone - Men Included. Ted Talk. [Accessed on 20 Oct. 2019]. Retrieved from: https://www.youtube.com/watch?v=7n9IOH0NvyY

Martin Chautari (2009). Media Training Trends and Practices in Nepal: A Status Report. Kathmandu: Martin Chautari. Retrieved from: http://www.martinchautari.org.np/files/media_training_tr ends.pdf

Nayapatrika (8 March 2020). Female Journalist: Maximum Women Leave Job When They Reach to 30 Year Age [headline, translated from Nepali]. Retrieved from: https://www.nayapatrikadaily.com/newsdetails/38159/2020-03-08?fbclid=IwAR02YfXS_bMrN8WKo-

JV3dlZeGqP6NiWGuyQ4zSltNhJxi541372qWQ1SM
Nepalnews.com (22 May 2014). Women Journalists' Conference in Kathmandu. Retrieved from: https://www.youtube.com/watch?v=XRghPaTeoig

Pandey B (2017). Women in Nepali Politics. Kathmandu: Retrieved from: https://www.gefont.org/assets/upload/pressarticles/Wome $\underline{\text { n,_Gender_and_Mass_media_in_Nepal_(by_Binda_Pand }}$ ey).pdf

Peiser W (2000). Setting the journalist agenda: Influences from journalists' individual characteristics and from media factors. Journalism \& Mass Communication Quarterly, 77(2), 243-257.

Ross K (2004) Sex at work: gender politics and newsroom culture. In: de Bruin M and Ross K (Eds.) Gender and Newsroom Culture: Identities at Work, Creskill, NJ: Hampton Press, pp. 145-162.

Sancharika Samuha (2015). Women Journalists in Nepal: Research on Professional Status of Women Journalists in Nepal. Kathmandu: Sancharika Samuha.

Shrestha R (2005) Women Journalists in Nepal. Media Asia 32(1): DOI: https://doi.org/10.1080/01296612.2005.11726767.

World Economic Forum (2018). The Global Competitiveness Report 2018. Retrieved from: TheGlobalCompetitivenessReport2018.pdf (weforum.org) 